\title{
Epilepsziasebészeti beavatkozások eredményei a Pécsi Epilepszia Centrumban 2005 és 2016 között
}

\author{
Lőrincz Katalin Nóra dr. ${ }^{1}$ - Bóné Beáta dr. ${ }^{1}$ - Tóth Márton dr. ${ }^{1}$ \\ Horváth Réka dr. ${ }^{1}$ - Kovács Norbert dr. ${ }^{1,7}$ - Komoly Sámuel dr. ${ }^{1,7}$ \\ Karádi Kázmér dr. ${ }^{4}$ - Barsi Péter dr. ${ }^{3,6}$ - Ábrahám Hajnalka dr. ${ }^{5}$ \\ Seress László dr. ${ }^{5}$ - Horváth Zsolt dr. ${ }^{2}$ - Dóczi Tamás dr. ${ }^{2,6,7}$ \\ Janszky József dr. ${ }^{1,7}$. Gyimesi Csilla dr. ${ }^{1}$
}

\footnotetext{
${ }^{1}$ Pécsi Tudományegyetem, Általános Orvostudományi Kar, Neurológiai Klinika, Pécs

${ }^{2}$ Pécsi Tudományegyetem, Általános Orvostudományi Kar, Idegsebészeti Klinika, Pécs

${ }^{3}$ Semmelweis Egyetem, Általános Orvostudományi Kar, MR Kutatóközpont, Budapest

${ }^{4}$ Pécsi Tudományegyetem, Általános Orvostudományi Kar, Magatartástudományi Intézet, Pécs

${ }^{5}$ Pécsi Tudományegyetem, Általános Orvostudományi Kar, Orvosi Biológiai Intézet és Központi Elektronmikroszkópos Laboratórium, Pécs

${ }^{6}$ Pécsi Diagnosztikai Központ, Pécs
}

${ }^{7}$ PTE-MTA Klinikai Idegtudományi Képalkotó Kutatócsoport, Pécs

\begin{abstract}
Bevezetés: Az epilepszia krónikus, súlyos neurológiai betegség, mely jelentősen befolyásolja az életminőséget. A megfelelő indikációval végzett epilepsziasebészeti beavatkozás rohammentességet eredményezhet, mely önmagában vagy rehabilitációt követően jelentősen javíthatja az életminőséget.

Célkitüzés: Jelen tanulmányunk célkitüzése a Pécsi Epilepszia Centrumban 2005 és 2016 között epilepsziasebészeti beavatkozáson átesett betegek posztoperatív eredményeinek felmérése.

Módszer: Az adatgyüjtés a betegek klinikai anyagának áttekintésén túlmenően kérdőívek alkalmazásával történt, a rohamállapot értékelésén kívül a foglalkoztatottsági státuszra mint az életminőség egyik fontos indikátorára is fókuszálva.

Eredmények: Reszektív epilepsziasebészeti beavatkozás 72 esetben történt. A betegek $76 \%$-a tartósan rohammentessé vált. A betegek 10\%-ánál mútét után csak igen ritkán lépett fel roham, 7\%-uknak jelentősen csökkent a rohamszáma, míg 7\%-ban nem változott érdemben a rohamállapot. A rohammentes és a nem rohammentes betegek csoportjainak foglalkoztatottsági adatait vizsgálva azt találtuk, hogy a rohammentesség befolyásolja a páciensek elhelyezkedési lehetőségeit. A rohammentes betegek $67 \%$-a állt foglalkoztatottság alatt, míg a nem rohammenteseknek mindössze a 19\%-a ( p $<0,01$, Fisher-féle egzakt teszt).

Következtetés: Eredményeink a nemzetközi adatoknak megfelelve alátámasztják az epilepszia reszektív sebészi kezelésének klinikai és szociális eredményességét.

Orv Hetil. 2019; 160(7): 270-278.
\end{abstract}

Kulcsszavak: epilepsziasebészet, posztoperatív rohamkimenetel, foglalkoztatottság, életminőség

Postoperative outcome of surgical interventions for epilepsy between 2005 and 2016 at the Epilepsy Center of Pécs

\footnotetext{
Introduction: Epilepsy as a chronic, severe neurologic disease significantly influences the quality of life of the epileptic patients. In candidates well selected for surgery, the seizure freedom is realistically achievable, and the quality of life can be further improved with complex individual rehabilitation.

Aim: We aimed to evaluate the postoperative outcome of patients who underwent epilepsy surgery between 2005 and 2016 at the Epilepsy Center at Pécs.

Method: We evaluated seizure status at regular follow-up visits after surgery and the quality of life using questionnaires focusing on employment and social status.
} 
Results: $76 \%$ of the 72 patients who underwent surgical resection for epilepsy were free from disabling seizures , and $10 \%$ had rare disabling seizures (almost seizure-free), $7 \%$ experienced worthwhile improvement and $7 \%$ had no worthwhile improvement. Comparing the employment status of patients free from disabling seizures to patients not free from disabling seizures, we found that the employment status is significantly influenced by seizure freedom ( $p<0.01$, Fisher's exact test). While $67 \%$ of seizure-free patients were employed, only $19 \%$ of patients not free from disabling seizures were hired.

Conclusion: Our results resemble the international tendencies and success rate, proving epilepsy surgery as an available, valid and effective treatment in well selected patients.

Keywords: epilepsy surgery, postoperative seizure outcome, employment status, quality of life

Lőrincz KN, Bóné B, Tóth M, Horváth R, Kovács N, Komoly S, Karádi K, Barsi P, Ábrahám H, Seress L, Horváth Zs, Dóczi T, Janszky J, Gyimesi Cs. [Postoperative outcome of surgical interventions for epilepsy between 2005 and 2016 at the Epilepsy Center of Pécs]. Orv Hetil. 2019; 160(7): 270-278.

(Beérkezett: 2018. október 1.; elfogadva: 2018. október 19.)

\section{Rövidítések}

$\mathrm{AE}=$ antiepileptikum; DNT $=$ diszembrioplasztikus neuroepithelialis tumor; EEG = elektroencefalográfia; $\mathrm{FCD}=$ fokális corticalis dysplasia; $\mathrm{fMR}=$ funkcionális MR; HIETE $=$ Hajnal Imre Egészségtudományi Egyetem; HS = hippocampalis sclerosis; MRI = (magnetic resonance imaging) mágnesesrezonancia-vizsgálat; OITI = Országos Idegsebészeti Tudományos Intézet; OPNI = Országos Pszichiátriai és Neurológiai Intézet; PET $=$ (positron emission tomography) pozitronemissziós tomográfia; PTE = Pécsi Tudományegyetem; SD = standard deviáció

Az epilepszia a stroke után a második leggyakoribb neurológiai betegség, mely Magyarországon megközelítőleg 50-60 ezer embert érint [1]. Az epilepszia krónikus állapot, melynek során életminőséget rontó tünetek és szövődmények alakulhatnak ki, jelentős terhet jelentve mind az egyén, mind a társadalom számára. Az epilepszia kezelésének három alappillére (1) a rohamok megfeleló - ideális esetben teljes - kontrollja, (2) a kezelés mellékhatásainak elkerülése és (3) a megfelelő életminôség biztosítása. A kezelés végső célja, hogy az epilepsziával éló beteg önmaga és a társadalom számára megbecsült egyénként tölthesse be szerepét képességeihez mérten $[2,3]$.

$\mathrm{Az}$ epilepszia kezelése antiepileptikum $(\mathrm{AE})$ segítségével történik, mely akár 60-70\%-ban rohammentességet eredményezhet $[4,5]$. Gyógyszer-rezisztencia - mely két adekvátan megválasztott és alkalmazott, jól tolerált AE sikertelensége után állapítható meg a Nemzetközi Epilepsziaellenes Liga definíciója alapján - esetén jön szóba bizonyos epilepsziaformákban a sebészeti beavatkozás lehetősége [6]. Az epilepsziasebészeti beavatkozás célja az epileptogén zóna eltávolítása vagy diszkonnekciója az elokvens cortex megkímélésével. Az epilepsziasebészet hatékony és biztonságos a preoperatív kivizsgálás alapján megfelelően indikált gyógyszerrezisztens betegek esetén [7]. Ennek ellenére, mint terápiás lehetőség, az epilepsziasebészet gyakran kihasználatlanul marad [8,
9]. A sebészeti beavatkozásra alkalmas betegeknél a korai operáció során érhetôk el a legkedvezőbb eredmények [10-13]. AE-rezisztencia jelentkezésekor javasolt tehát a minél korábban történő multimodális kivizsgálás, melynek célja az epileptogén zóna lokalizációja [14]. A kivizsgálás két fó eleme az epilepsziaprotokoll szerint végzett koponya-MRI- és a video-EEG-monitorozás során nyert EEG- és rohamfelvétel [15]. Egy sikeres epilepsziasebészeti beavatkozáshoz számos kritérium együttes jelenléte szükséges, melyek: a pontos szindrómadiagnózis, a farmakorezisztencia, az epileptogén zóna lokalizációjának ismerete, az elörevetíthetô rohammentesség, az alacsony mútéti rizikó és a beteg kellő motivációja.

Magyarországon jelenleg Budapesten, Debrecenben és Pécsett történnek epilepsziasebészeti beavatkozások.

A jelenlegi munkát nemzetközileg is ismert elődök alapozták meg. Az 1950-70-es évekből a Debreceni Idegsebészeti és Neurológiai Klinikán Hullay [16, 17], míg az Országos Idegsebészeti Tudományos Intézetben (OITI) Fényes [18] publikációi tudósítanak a korai epilepsziasebészeti beavatkozások eredményeiről. Az 1980as években ugrásszerúen megújult képalkotó lehetőségekre támaszkodó modern epilepsziasebészeti kivizsgálás magyarországi múhelyének megszervezése Halász Péter nevéhez kötődik. Rásonyi és mtsai összegzése alapján [19] az OPNI-HIETE Epilepszia Centrumban 1999-ig történt több mint 100 epilepsziasebészeti beavatkozás 67-79\%-ban eredményezett posztoperatív rohammentességet. Az Országos Pszichiátriai és Neurológiai Intézetben (OPNI) és az OITI-ben 1985 és 2001 között elülső temporalis lebenyi reszekción átesett betegek hosszú távú rohamkimeneti eredményeiről és az ezeket befolyásoló tényezókről Kelemen és mtsai [20] számoltak be. A budapesti Kooperatív Epilepsziasebészeti Program (az OITI, az OPNI, a Bethesda Gyermekkórház, a Szent János Kórház és a Szent István Kórház kooperációja) eredményeit Balogh és mtsai összegezték [21].

A Pécsi Neurológiai Klinikán Környei István vezette be az epilepsziasebészetet. Az epilepsziasebészeti kivizs- 
gálások módszeressé és rendszeressé válása, illetve az úgynevezett kooperatív epilepsziacentrum megalakulása - rutinszerú epilepsziasebészeti lehetőséget teremtve 2005-tól valósult meg a PTE Neurológiai Klinikájának és Idegsebészeti Klinikájának, illetve Magatartástudományi Intézetének és Biológiai Intézetének, valamint a Pécsi Diagnosztikai Központnak az együttmúködésével.

\section{Célkitüzés}

Célunk a Pécsi Epilepszia Centrumban 2005 és 2016 májusa között preoperatív kivizsgáláson, majd sebészeti beavatkozáson átesett betegek posztoperatív eredményeinek összegzése, nemzetközi adatokhoz hasonlítása volt, figyelmet fordítva a posztoperatív pszichoszociális, ezen belül kiemelten a foglalkoztatottsági állapotra.

\section{Módszer}

Az adatgyüjtés részben retrospektív módon, kórlapok adatainak áttekintésével (pre- és perioperatív adatok), részben prospektív módon, aktuális adatok gyüjtésével, célzott kérdésfeltevéssel történt kontrollvizsgálatok és telefonos konzultációk során.

A betegek preoperatív kivizsgálásának része volt a részletes anamnézisfelvétel, az antiepileptikumrefrakter epilepszia megállapítása, a nagy felbontású (1.5-3 tesla), epilepsziaprotokoll szerinti MRI-felvételek készítése [22] , 2-10 napos video-EEG-monitorizálás, neuropszichológiai kivizsgálás és a szociális helyzet értékelése, továbbá szükség esetén a pozitronemissziós tomográfia. $\mathrm{Az}$ epilepsziasebészeti kivizsgálást multidiszciplináris

Engel I. Rohammentesség

- A. Teljes rohammentesség a sebészeti beavatkozás óta

- B. Csak aurajelenség lép fel

- C. Mútét után néhány roham, de minimum 2 éve tartósan rohammentes

- D. Antipileptikumelhagyásra fellépett egyszeri roham

Engel II. Ritka rohamok

- A. Kezdeti rohammentesség után megjelenő ritka rohamok

- B. Ritka rohamok mütét óta

- C. Alkalomszerú rohamok a mütét óta, az utóbbi két évben ritkán

- D. Csak éjszakai rohamok

Engel III. Érdemben javult rohamállapot

- A. Jelentősen csökkent rohamszám

- B. Tartósan rohammentes állapot a követési időszak több mint felénél hosszabb időben, de kevesebb mint 2 évig

Engel IV. Nincs érdemi javulás

- A. Mérsékelt rohamszámcsökkenés

- B. Változatlan rohamstátusz

- C. Rohamstátusz rosszabbodása

1/a ábra | Engel-féle klasszifikációs rendszer team - neurológus, idegsebész, neuroradiológus, neuropszichológus és szükség esetén pszichiáter - értékelte, meghatározta a mútét lehetőségét, megbecsülte a várható epileptológiai, kognitív, pszichiátriai és szociális kimenetet és a várható mưtéti szövődményt. Mindezek ismeretében végül a betegek döntöttek, hogy történjen-e mútéti beavatkozás.

A reszektív sebészeti beavatkozások utáni rohamkimenetel értékelése az Engel-klasszifikáció alapján ( $1 / a$ ábra) történt [23]. Követő MRI- és neurokognitív vizsgálatok a mútét után fél és két évvel zajlottak. Az eredmények értékelése a rendszeres kontrollvizsgálatok keretében, illetve az aktuális adatok gyújtése kérdőív segítségével, telefonon történt. A kérdőív az aktuális rohamállapot mellett az antiepileptikumszedést és a társadalmi szerepek bizonyos részterületeit érintette, elsősorban a munkaképességre és a megvalósult munkavállalásra vonatkozott.

Vizsgáltuk továbbá az epilepsziabetegség korlátozó hatását a páciens családi életére, mindennapi tevékenységeire nézve. A korlátozó hatás mértékét a páciensek maguk értékelték az EuroQoL (EQ-5D) általános életminőséget felmérő kérdőív „Szokásos tevékenységek” pontja alapján, 5 fokozatú skálán, az alábbiak szerint [24]:

1. Nincs problémám a szokásos tevékenységeim elvégzésével.

2. Enyhe problémám van a szokásos tevékenységeim elvégzésével.

3. Közepes fokú problémám van a szokásos tevékenységeim elvégzésével.

4. Súlyos problémám van a szokásos tevékenységeim elvégzésével.

5. Képtelen vagyok elvégezni a szokásos tevékenységeimet.

A „Szokásos tevékenységek”-et a munka, a tanulás, a házimunka, a családi vagy szabadidős programok területén értékelték a páciensek.

\section{Eredmények}

Reszektív epilepsziasebészeti beavatkozáson a Pécsi Epilepszia Centrumban 2005 és 2016 májusa között 72 beteg esett át. A nemek aránya nem különbözött érdemben (nő: 54\%, férfi: 46\%). A legfiatalabb beteg 9 éves, a legidősebb 63 éves volt a mütét idején, az átlagos életkor 37 év volt (SD: 11,39). Az epilepszia a mútét előtt átlagosan 21 éve állt fenn (SD: 14,00), 52 betegnél több mint 10 éve.

A posztoperatív rohamállapot értékelése 71 beteg esetén történt meg. Vizsgálatunkban a betegek mútét utáni rohamállapotának felmérése 2016-ban, a mútétet követően 1 és 10 év közötti időtávlatban történt. Az átlagos követési idő 5,2 év volt. (1-2 éves követési időszak 19 páciens, 3-5 éves 18 páciens, 6-10 éves 33 beteg esetén valósult meg.) Rohammentességet (Engel I.) a betegek 76\%-a ért el. Ritkán még felléptek rohamai (Engel II.) a 


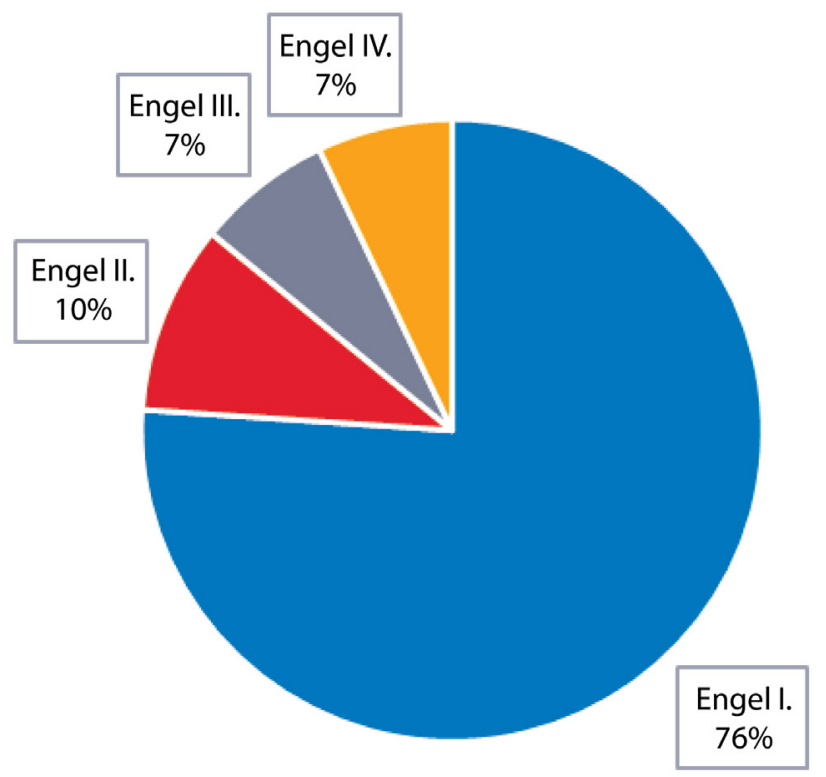

1/b ábra | Reszektív sebészeti beavatkozások, posztoperatív rohamállapot

betegek 10\%-ának, jelentősen csökkent a rohamszáma (Engel III.) 7\%-uknak, míg 7\%-uk esetén alig vagy nem történt változás a rohamgyakoriságban (Engel IV/a,b). Ezen eredményeket az $1 / b$ ábrán foglaltuk össze.

Az Engel I. rohamállapotú betegek közül - akiknek értékelhetó adata állt rendelkezésre az antiepileptikumaik változtatására vonatkozóan ( 43 beteg) - 16 betegnek (37\%) lehetett az antiepileptikumait teljesen elhagyni (mútét előtt egy-négyféle gyógyszert szedtek). Három kivételével a többi beteg esetén is csökkenteni lehetett a gyógyszerek számát, illetve dózisát.

A szövettani vizsgálatok alapján 37\%-ban hippocampalis sclerosis (HS), 28\%-ban tumorok (cavernoma, glioma, cholesteatoma, diszembrioplasztikus neuroepitheli- alis tumor [DNT], teratoma), 14\%-ban fokális corticalis dysplasia (FCD), 8\%-ban duálpatológia (HS és FCD együtt), 6\%-ban többes patológia (például HS és occipitalis cavernoma) és 4\%-ban komplex fejlődési rendellenesség igazolódott, míg a betegek 3\%-ában nem tudtunk epileptogén laesiót kimutatni [25] (2. ábra).

A mútét után teljes rohammentességet (Engel I/a) 41 beteg ért el. Ebben a csoportban külön megvizsgáltuk az etiológiai tényezóket: hippocampalis sclerosis $37 \%$-ban, cavernoma 19\%-ban, glioma 12\%-ban, fokális corticalis dysplasia és duálpatológia 10-10\%-ban, cholesteatoma és többes patológia (HS és DNT, illetve HS és posthaemorrhagiás gliosis együtt) 5-5\%-ban, míg DNT 2\%-ban fordult elő (3. ábra).

Temporalislebeny-epilepsziája 63 betegnek volt. Ezen alcsoport posztoperatív rohamállapotát vizsgálva azt találtuk, hogy 49 beteg (78\%) az Engel I., 7 beteg (11\%) az Engel II., 5 beteg (8\%) az Engel III., míg 2 beteg (3\%) az Engel IV. csoportba tartozott.

Extratemporalis epilepszia 8 betegnél fordult elő. Teljes rohammentességet (Engel I/a) 4 beteg ért el, 1 beteg esetén antiepileptikummegvonásra jelentkezett generalizált rosszullét (Engel I/d), míg 3 beteg esetén nem volt jelentős rohamszámcsökkenés (Engel IV/a, b). Az extratemporalis epilepszia etiológiai tényezóiként tumorok (oligodendroglioma, cavernoma) (3 beteg), fokális corticalis dysplasia ( 3 beteg), illetve többes patológia (ganglioglioma és FCD, HS és occipitalis cavernoma) (2 beteg) igazolódott.

Vizsgálatunk során számba vettük az epilepsziasebészeti beavatkozások szövődményeit is: a posztoperatíve követett 7l beteg közül kettő esetében látótérkiesés jelentkezett, egy betegnél fejfájás, szédülés maradt vissza.

Vizsgálatunk másik fontos kérdésköre volt, hogy epilepsziasebészeti beavatkozás után miként változnak a páciensek társadalmi szerepei, a munkavállalás során, illetve

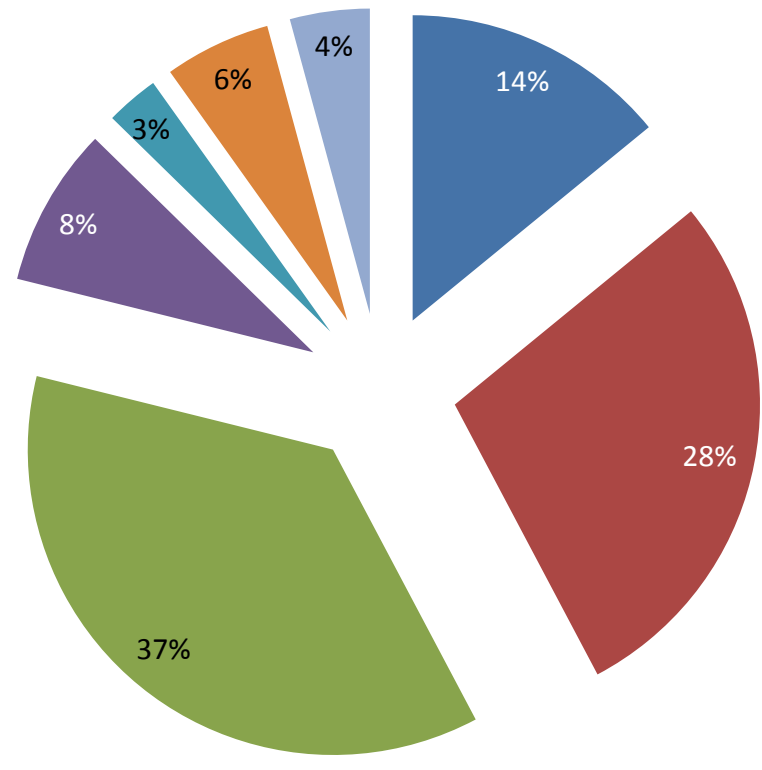

2. ábra

\footnotetext{
Reszektív sebészeti beavatkozások etiológiája
}

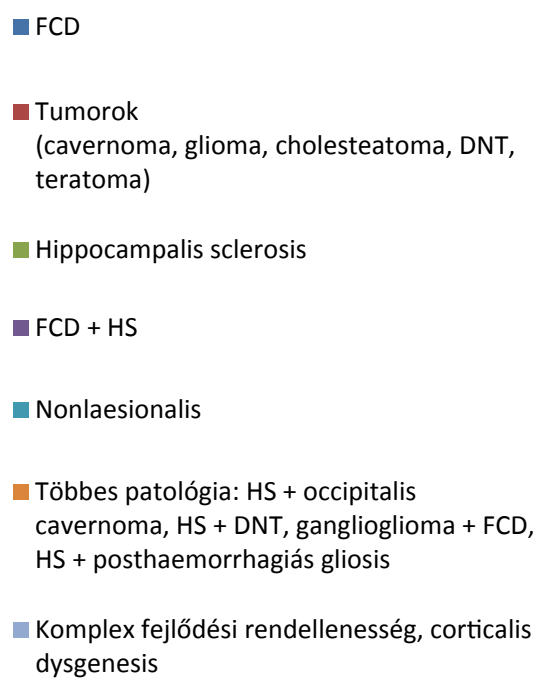



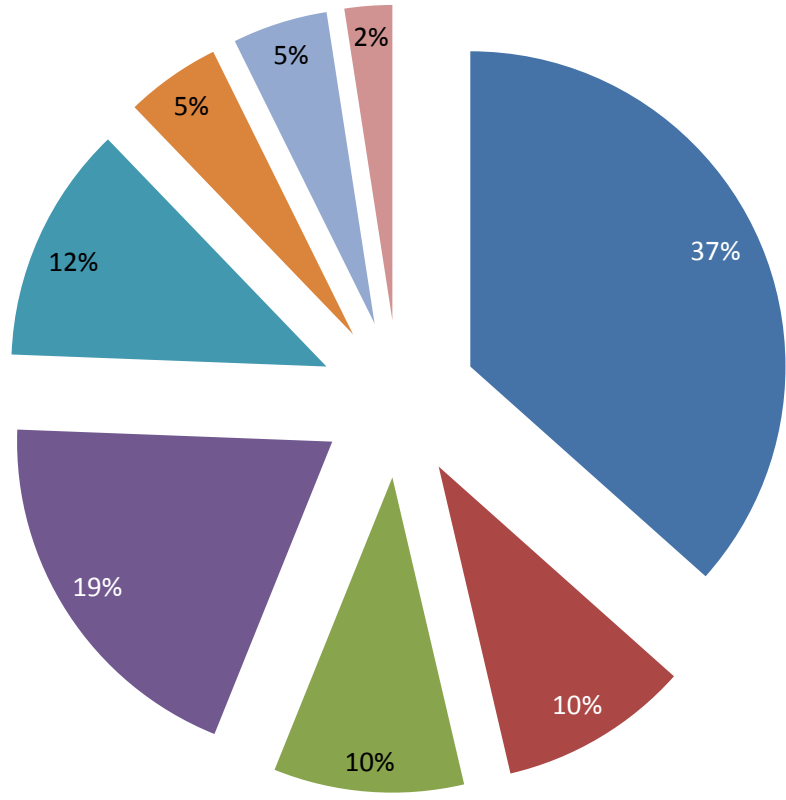

a családban végzett tevékenységei. E kérdés alapvetően a betegek életminősége szempontjából fontos, de hasznos lehet az epilepsziabetegségből gyógyulók rehabilitációjának megszervezésére vonatkozóan is. Vizsgálatunkban az epilepsziasebészeti beavatkozás után követett 71 beteg közül 61 beteg válaszolt a foglalkoztatottsággal, családi szerepekkel kapcsolatos kérdéseinkre. 33 beteg nyilatkozott úgy, hogy foglalkoztatott (54\%), míg 28 beteg nem tudott elhelyezkedni (46\%).

Az epilepsziasebészeti beavatkozás utáni foglalkoztatottsági státusz jelentősen befolyásolhatja az életminőséget. Az Engel I/a csoportban a betegek 67\%-a állt foglalkoztatás alatt. 9\%-uk sikeres, teljes rohammentességet eredményező mútét után tudott elhelyezkedni, 37\%-uk mútét előtt és után is hátrányos megkülönböztetés nélkül dolgozott, míg a betegek 21\%-át megítélésük szerint munkahelyükön hátrányos megkülönböztetés érte. A teljes rohammentességet elérő betegek 33\%-a nem állt foglalkoztatás alatt, társadalmi státuszukban a sikeres mütét ellenére sem történt változás. Az Engel I/b, c, d csoportban a betegeknek szintén a $67 \%$-a állt foglalkoztatottság alatt, 4l\%-uk hátrányos megkülönböztetés nélkül, 25\%-uk hátrányos megkülönböztetés mellett. Ebben a csoportban a betegek egyharmada (33\%) nem tudott elhelyezkedni, egyikük éppen az epilepsziasebészeti mútét után vesztette el munkáját.

Az Engel II. csoportbeliek 34\%-a tudott elhelyezkedni hátrányos megkülönböztetés nélkül vagy hátrányos megkülönböztetéssel, egyenlő arányban. A betegek 66\%-a nem állt foglalkoztatottság alatt, közülük egy beteg a mütét után vesztette el munkahelyét. Az Engel III. csoportban a betegek $20 \%$-a kapott állást a mütét után, míg 80\%-uk nem tudott elhelyezkedni. Az Engel IV. csoportban egy beteg sem állt foglalkoztatottság alatt.
A foglalkoztatottsági adatokat a posztoperatív rohamstátusz függvényében a 4. ábrán foglaltuk össze.

A foglalkoztatottság terén nem voltak nemi különbségek. Az értékelt 31 nő- és 30 férfi beteg adatai alapján a nők 52\%-a és a férfiak 56\%-a volt foglalkoztatott. A posztoperatív rohamállapot nemek szerinti értékelése során érdemi különbség nem mutatkozott.

Az Engel I. (rohammentes) és az Engel II-IV. (nem rohammentes) csoportok foglalkoztatottsági adatait vizsgálva azt találtuk, hogy a rohammentesség szignifikánsan befolyásolja ( $\mathrm{p}<0,01$, Fisher-féle egzakt teszt) a páciensek elhelyezkedési lehetőségeit. A rohammentes (Engel I.) betegek 67\%-a állt foglalkoztatottság alatt, míg a nem rohammenteseknek (Engel II-IV.) mindöszsze a $19 \%$-a.

A családi élet és a mindennapi tevékenységek körében is kértük a betegeket, hogy értékeljék tevékenységüket, összehasonlítva a mútét előtti állapottal. A „Szokásos tevékenységek" ellátásának minőségét a mütét előtti és utáni állapot összehasonlításával a betegek kérdőív segítségével értékelték egy ötfokú skálán. A szokásos tevékenységek alatt a munkát, tanulást, házimunkát, családi vagy szabadidős tevékenységeket jellemezték. Az 5. ábra grafikonja a mütét előtti és utáni értékelés különbségét ábrázolja. A legnagyobb változás az Engel I. csoportban történt, ahol a betegek túlnyomó többsége javulásról számolt be (akár 4 fokozat javulás is előfordult 2 betegnél [5\%]). Nagyfokú (3 fokozat) javulásról 12 beteg (27\%), közepes javulásról 19 beteg (43\%), kisfokú javulásról 8 beteg (18\%) számolt be, míg 3 beteg esetén (7\%) nem történt változás a mútét előtti állapothoz képest. Az Engel II. csoportban nagyfokú javulás (3 fokozat) következett be 1 betegnél (17\%), közepes fokú javulás ( 2 fokozat) 2 betegnél (33\%), míg kisfokú javulásról (1 fokozat) a betegek fele számolt be. Az Engel III. csoportban 


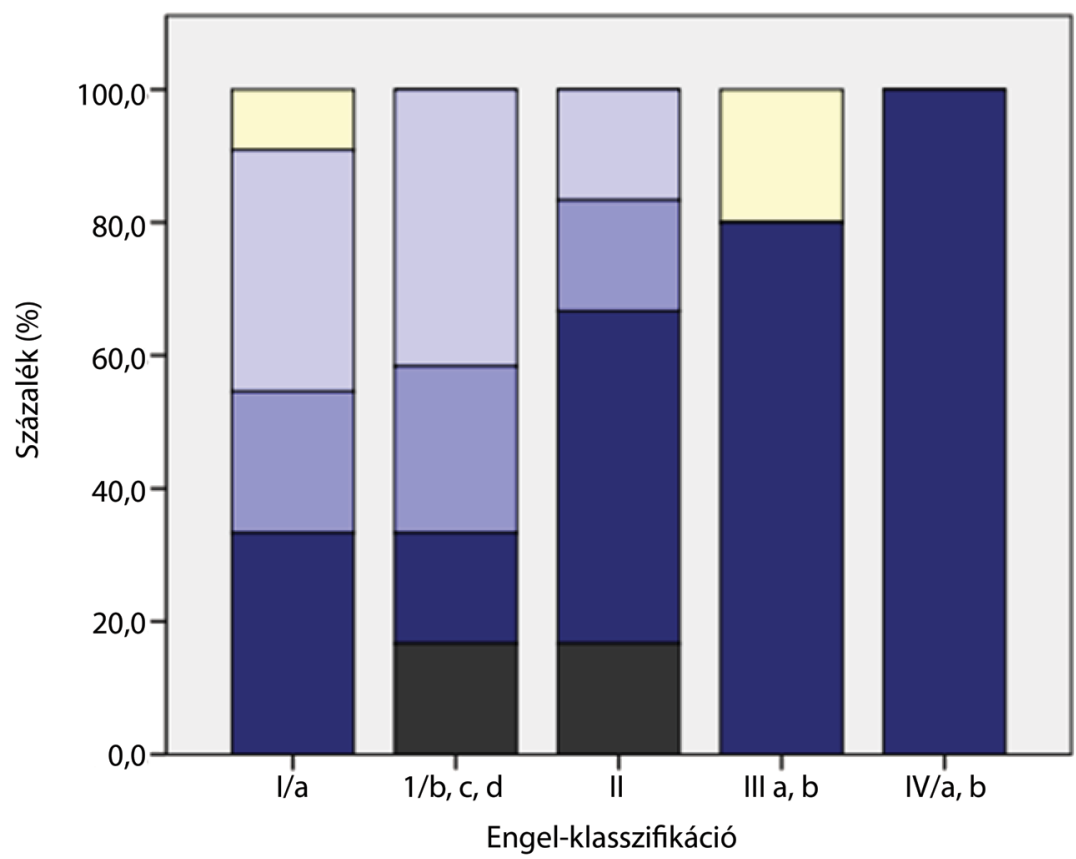

\section{Foglalkoztatottság}

$\square$ Mútét óta foglalkoztatott

$\square$ Foglalkoztatott, epilepszia miatt nem érte hátrányos megkülönböztetés

$\square$ Foglalkoztatott, epilepszia miatt hátrányos megkülönböztetés érte

Nem állt foglalkoztatás alatt sem mütét előtt, sem mütét után

Mútét után vesztette el munkáját

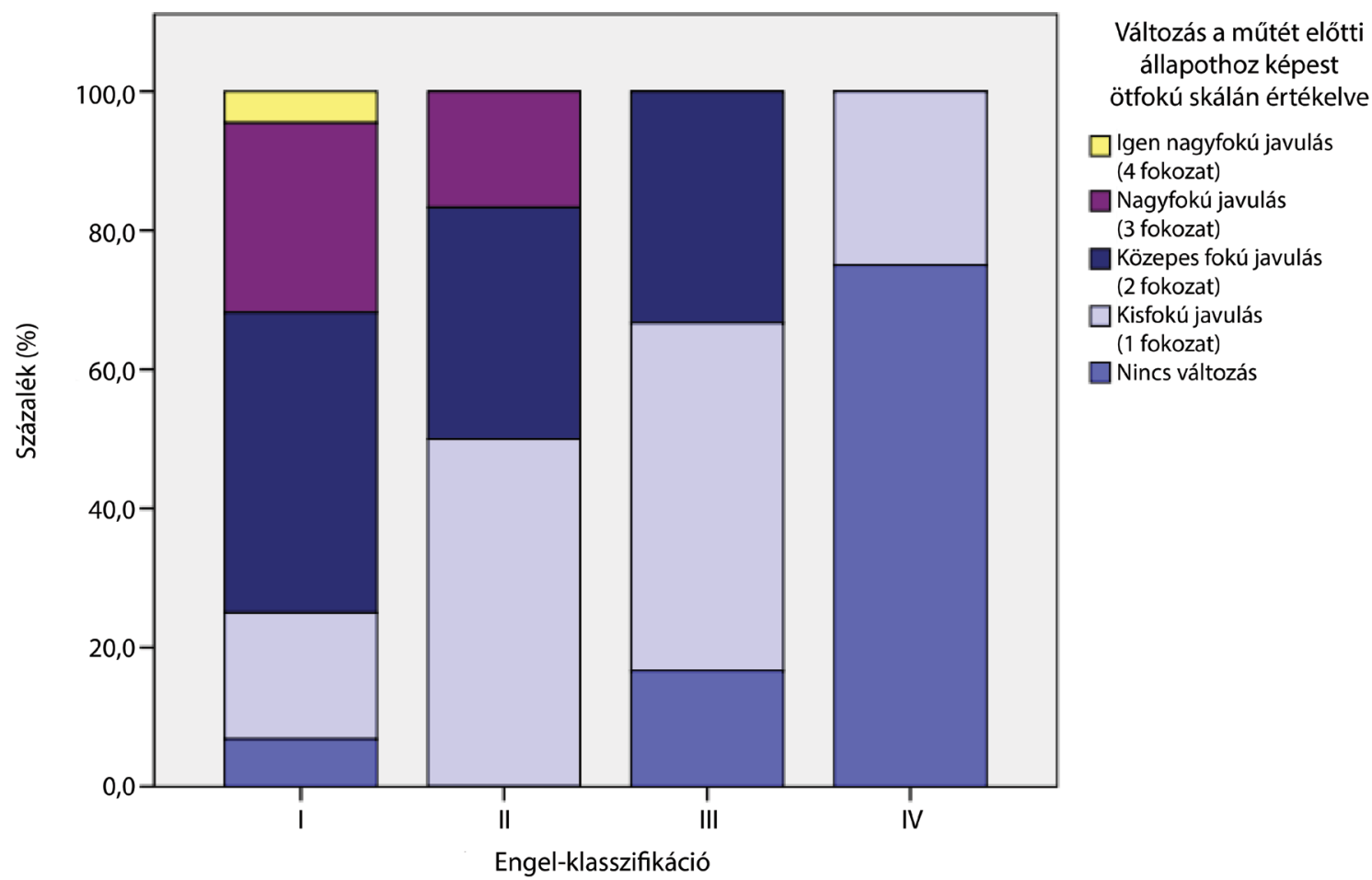

5. ábra | Családi élet, mindennapi tevékenységek ellátása

közepes javulás 2 betegnél (33\%), kisfokú javulás 3 betegnél $(50 \%)$ történt, míg egy beteg (17\%) változatlan állapotról számolt be. Az Engel IV. csoportban enyhe javulás is csak az esetek kisebb részében mutatkozott kisfokú javulás l betegnél $(25 \%)-$, míg a betegek nagyobb része, 3 beteg $(75 \%)$ esetében nem történt javulás a mútét előtti állapothoz képest.

\section{Megbeszélés}

$\mathrm{Az}$ epilepsziasebészet célja a rohammentesség elérése, ezzel a betegek életminőségének javítása, a kiteljesedett családi élet és karrier lehetőségének biztosítása, mely lehetôvé teszi az epilepsziás beteg számára a képességeinek megfelelő társadalmi beilleszkedést $[2,3,14]$. 
Az életminőség javulását érdemben a rohammentesség elérése hozhatja meg a betegek számára, melyet a reszektív epilepsziasebészeti beavatkozások eredményezhetnek a legnagyobb hatékonysággal (etiológia és lokalizáció függvényében 50-90\%-ban) [26] az antiepileptikumrezisztens fokális epilepsziával élőknél. A Pécsi Epilepszia Centrumban az elmúlt tíz évben történt epilepsziasebészeti kivizsgálások és beavatkozások célja is ez volt. Vizsgálatunk alapján elmondható, hogy a reszektív epilepsziasebészeti beavatkozás után betegeink rohamállapota a nemzetközi adatokhoz hasonlóan alakult, hiszen az öszszes beteg 76\%-a, illetve a temporalislebeny-epilepsziás betegek 78\%-a vált rohammentessé [7, 27-30]. Ez az arány hasonló a nemzetközi és hazai eredményekhez, igazolva, hogy az epilepsziasebészet eredményessége nem ország-, illetve régiófüggő.

Az összes beteg adatait tekintve, rohamállapottól függetlenül vizsgálva, a betegek 54\%-a tudott dolgozni. Egyharmaduk vélte úgy, hogy munkavállalása során hátrányos megkülönböztetés éri, ami a pályázó epilepszia miatti elutasítása, csak képzettségi szintje alatti munkakör betöltésének engedélyezése, képességeinek nem valós megítélése és az epilepsziabetegség miatti előítélet tanúsításában nyilvánult meg. Ezen betegek közül többen említették, hogy több, epilepszia miatt elutasított álláspályázatuk után elhallgatták betegségüket, így tudtak álláshoz jutni, megítélésük szerint másképp nem alkalmazták volna őket. Az epilepszia napjainkban is stigmatizációval és izolációval jár [31], és az epilepsziabetegséget nem megfelelően ismerő társadalom elutasító magatartása a betegek szorongását jelentősen növeli, rontva ezzel akár a rohammentességet elért betegek életminőségét is.

A rohamstátusz az életminőség egyik fontos meghatározója, és vizsgálati eredményeink alapján befolyásolja a betegek foglalkoztatottsági státuszát is, hiszen az Engel I. csoportban a betegek 67\%-a dolgozott, míg az Engel II. csoportban csak 34\%-uk, az Engel III. csoportban 20\%-uk és az Engel IV. csoportban egy beteg sem.

A mútét utáni rohammentesség az életminőség alakításában fontos szerepet játszik [32], hasonlóan fontos szerep jut azonban a beteg környezetének, támogató vagy elutasító magatartásának, a stigmatizációnak is [33]. Míg Magyarország a posztoperatív rohammentesség tekintetében a nemzetközi standardokat követő eredményekkel igazolja az epilepsziasebészeti beavatkozás hatékonyságát, a szociális rehabilitáció, a társadalmi edukáció terén felmerülő hiányosságok jelentős terhet róhatnak az immár rohammentessé vált, társadalomba visszailleszkedni kívánó, éveken át izolálódott, stigmatizációt tapasztalt betegekre [34]. Az OPNI területén müködő komplex epilepsziarehabilitációs központ (Valentin Ház) 2007-ben történő bezárását követően hazánkban sajnos nincs specializált epilepsziarehabilitáció.

Az egyénre szabott rehabilitáció az európai országok közül több helyen, így például Németországban is magas színvonalú, ahol epilepsziarehabilitációra specializálódott centrumokban megvalósították az akár többhetes benntartózkodású, akár utógondozói ambuláns megjelenéssel járó rehabilitációt, melynek során biztosított az interdiszciplináris szemlélet neuropszichológus, pszichológus, pszichiáter, szociális munkás, beszédterapeuta, karriertanácsadó, gyógytornász részvételével [35]. A rehabilitáció kiterjed a memóriazavarok feltérképezésére, neuropszichiátriai vizsgálatra, pszichológiai tanácsadásra, pszichiátriai komorbiditás esetén pszichiátriai gondozásra, az epilepsziabetegség helyes egyéni megítélését segítő edukációra a páciens és a hozzátartozók, az epilepsziás beteggel élők számára [36-39]. Ezen speciális komplex rehabilitáció magában foglalja a szociális rehabilitációt, a beteg elhelyezkedését segítő tanácsadást, állásinterjúra felkészítést, személyre szabott mozgásrehabilitációt, tanácsadást a sportolási lehetőségekről, a kognitív, illetve beszédzavarok diagnosztizálását, kezelését, a munkahelyi terhelhetőség fokozását, a lelki állóképesség növelését, stabilitást segítő tréningeket.

A betegek szubjektív értékelése alapján a rohamállapot változása fontos tényező a családban betöltött szerep, illetve a mindennapi tevékenységek ellátása tekintetében. Az Engel I. csoportban a betegek 93\%-a, míg az Engel IV. csoportban a betegek $25 \%$-a számolt be javulásról. Azon betegeknél, akik nem tapasztaltak változást a rohamállapotuk jelentős javulása ellenére, előrelépés várható a családot is bevonó rehabilitációtól, pszichológiai tanácsadástól, melyek a rohamállapoton kívüli életminőséget csökkentő faktorok feltérképezésével nyújthatnak segítséget a betegnek és hozzátartozóinak. Az egyénre szabott rehabilitáció sokrétü és körültekintő megszervezése szükséges tehát [40].

A mütétek epilepsziasebészeti kooperatív centrumok múködését teszik szükségessé, biztosítva a betegek számára a komplex interdiszciplináris kivizsgálás, a kellő gyakorlattal bíró operatőr általi mütéti beavatkozás és a pszichoszociális aspektusokat sem nélkülöző rehabilitáció együttes lehetőségét. Manapság a mütét előtti kivizsgálás önmagában is több szakma együttes, speciális ismereteit igényli: magas szintû epileptológiai tudást, elektrofiziológiai ismereteket (skalpi mellett szükség esetén invazív elektródák alkalmazását is), speciális képalkotó eljárások alkalmazását (MR-, fMR- és PET-vizsgálatok), valamint sebészeti részvételt $[9,14,15,41]$. Mindezek, kiegészülve az Idegsebészeti Klinikán mára rutinszerüen alkalmazott reszektív és funkcionális sebészeti eljárásokkal, rendelkezésre állnak a 2005-ben szerveződött és fokozatosan építkező pécsi kooperatív epilepsziasebészeti centrumban. Az utógondozás neurológiai-epileptológiai szempontból rutinszerúen zajlik; viszont egy szervezett, speciális pszichoszociális rehabilitáció kiépítése még feladatunk, mely biztosíthatja az epilepsziasebészeti mútéten átesett betegek számára a kiteljesedett fizikai, szellemi és érzelmi élet lehetőségét [42]. 
Anyagi támogatás: A közleményt az EFOP-3.6.2-162017-00008-as számú, „A neuroinflammáció vizsgálata a neurodegeneratín folyamatokban: a molekulától a betegágyig” című grant támogatta.

Szerzői munkamegosztás: L. K. N.: A betegadatok gyújtése és feldolgozása, irodalmi adatok gyújtése, a cikk írása. J. J., Gy. Cs.: Tanácsadás az adatok gyújtésére és feldolgozására, a következtetések levonására. A szakmai profiljának megfelelően valamennyi szerző részt vett a betegek pre-, operatív és posztoperatív vizsgálatában, illetve ellátásában. A cikk végleges változatát valamennyi szerző elolvasta és jóváhagyta.

Érdekeltségek: A szerzóknek nincsenek érdekeltségeik.

\section{Köszönetnyilvánítás}

Horváth Rékát „Az Emberi Erőforrások Minisztériuma ÚNKP-17-4 I-PTE-139 kódszámú Új Nemzeti Kiválóság Programja” támogatta.

\section{Irodalom}

[1] Ministry of National Resources guideline for diagnosing epileptic seizures and epilepsy, treatment and care of epileptic patients. [Az Emberi Erőforrások Minisztériuma szakmai irányelve az epilepsziás rohamok és epilepszia felismeréséról, kezeléséról és az epilepsziás betegek gondozásáról.] Egészségügyi Közlöny 2017; 66: 689-720. [Hungarian]

[2] Schachter SC. Advances in the assessment of refractory epilepsy. Epilepsia 1993; 34: 24-30.

[3] Schachter SC. Update in the treatment of epilepsy. Compr Ther. $1995 ; 21: 473-479$

[4] Kwan P, Brodie M. Issues of medical intractability for surgical candidacy. In: Wyllie E, Gupta A, Lachhwani D. (eds.). Lippincott, Williams \& Wilkins, Philadelphia, PA, 2006; p. 983. The treatment of epilepsy and practice.

[5] Devinsky O. Patients with refractory seizures. N Engl J Med. 1999; 340: 1565-1570.

[6] Kwan P, Arzimanoglou A, Berg AT, et al. Definition of drug resistant epilepsy: consensus proposal by the ad hoc Task Force of the ILAE Commission on Therapeutic Strategies. Epilepsia 2010; 51: 1069-1077.

[7] Wiebe S, Blume WT, Girvin JP, et al. A randomized, controlled trial of surgery for temporal-lobe epilepsy. N Engl J Med. 2001; 345: 311-318.

[8] Jetté N, Sander JW, Keezer MR. Surgical treatment for epilepsy: the potential gap between evidence and practice. Lancet Neurol. 2016; 15: 982-994

[9] Halász P. Successful epilepsy surgery: why is it still underutilized? [Sikeres epilepszia mütétek: miért nem használjuk ki a lehetőséget?] Med Tribune 2010; 12: 10. [Hungarian]

[10] Engel J Jr, McDermott MP, Wiebe S, et al. Design considerations for a multicenter randomized controlled trial of early surgery for mesial temporal lobe epilepsy. Epilepsia 2010; 51 : 1978-1986

[11] Engel J Jr, McDermott MP, Wiebe S, et al. Early surgical therapy for drug-resistant temporal lobe epilepsy: a randomized trial. JAMA 2012; 307: 922-930.

[12] Simasathien T, Vadera S, Najm I, et al. Improved outcomes with earlier surgery for intractable frontal lobe epilepsy. Ann Neurol. 2013; 73: 646-654

[13] Janszky J, Janszky I, Schulz R, et al. Temporal lobe epilepsy with hippocampal sclerosis: predictors for long-term surgical outcome. Brain 2005; 128: 395-404.
[14] Janszky J, Gyimesi C, Horváth R, et al. Surgical treatment of epilepsy. In: Janszky J, Fogarasi A. (eds.) Clinical epileptology. [Az epilepszia sebészi kezelése. In: Janszky J, Fogarasi A. (szerk.) Klinikai epileptológia.] Medicina Könyvkiadó, Budapest, 2017; pp. 281-282. [Hungarian]

[15] Janszky J, Rásonyi G, Fogarasi A, et al. Surgically treatable epilepsy. A review. [Mútéttel gyógyítható epilepszia: Összefoglaló tanulmány.] Orv Hetil. 2001; 142: 1597-1604. [Hungarian]

[16] Gombi R, Velok G, Hullay J. The value of electrostimulation in epileptic focus localisation. Acta Neurochirurgica 1976; 23: 1520.

[17] Hullay J. Experiences in surgery of focal epilepsy. [Focális epilepsia-mútétek kapcsán szerzett tapasztalataink.] Ideggyógy Szle. 1955; 8: 103-112. [Hungarian]

[18] Fényes I, Zoltan L, Fenyes G. Temporal epilepsies with deepseated epileptogenic foci. Postoperative course. Arch Neurol. 1961; 4: 559-571.

[19] Rásonyi G, Halász P, Vajda J, et al. The outcome of surgery in patients of OPNI-HIETE Center in operations performed between 1992-1997. 4th Congress of the Hungarian Chapter of the ILAE [Az OPNI-HIETE Epilepszia Centrum betegeinél 1992 és 1997 között végzett epilepszia mútétek kimenetele. A Nemzetközi Epilepsziaellenes Liga Magyar Tagozatának 4. Kongresszusa.] Hévíz, 1999. november 3. [Hungarian]

[20] Kelemen A, Barsi P, Erôss L, et al. Long-term outcome after temporal lobe surgery - prediction of late worsening of seizure control. Seizure 2006; 15: 49-55.

[21] Balogh A, Borbély K, Czirják S, et al. Experiences of surgically treated temporal epileptic patients - multicentre study. [Tapasztalataink a temporális epilepsziás betegek mútéti kezelésével többközpontú vizsgálat.] Ideggyógy Szle. 1997; 50: 221-232. [Hungarian]

[22] Barsi P. Magnetic resonance measuring and analitic methods in epilepsy. [Mágneses rezonanciás mérési és adatfeldolgozó módszerek epilepsziában.] Ideggyógy Szle. 2011; 64: 300-304. [Hungarian]

[23] Durnford AJ, Rodgers W, Kirkham FJ, et al. Very good interrater reliability of Engel and ILAE epilepsy surgery outcome classifications in a series of 76 patients. Seizure 2011;20: 809812.

[24] Fábián G. Standardized questionnaires to measure health status. Chapter 12. In: Fábián G. (ed.) Applied Research Methodology. [Standardizált kérdőívek az egészségi állapot mérésére. 12. fejezet. In: Fábián G. (szerk.) Alkalmazott kutatás módszertan.] Debreceni Egyetem Egészségügyi Kar, Debrecen, 2014. [Hungarian]

[25] Semah F, Picot MC, Adam C, et al. Is the underlying cause of epilepsy a major prognostic factor for recurrence? Neurology 1998; 50: 1256-1262

[26] Geschwind M, Seeck M. Modern management of seizures and epilepsy. Swiss Med Wkly. 2016; 146: 14310.

[27] Tellez-Zenteno JF, Hernandez Ronquillo L, Moien-Afshari F, et al. Surgical outcomes in lesional and non-lesional epilepsy: a systematic review and meta-analysis. Epilepsy Res. 2010; 89: 310318.

[28] Mathon B, Bédos Ulvin L, Adam C, et al. Surgical treatment for mesial temporal lobe epilepsy associated with hippocampal sclerosis. Rev Neurol. 2015; 171: 315-325.

[29] Elsharkawy AE, Alabbasi AH, Pannek H, et al. Long-term outcome after temporal lobe epilepsy surgery in 434 consecutive adult patients. J Neurosurg. 2009; 110: 1135-1146.

[30] McIntosh AM, Kalnins RM, Mitchell LA, et al. Temporal lobectomy: long-term seizure outcome, late recurrence and risks for seizure recurrence. Brain 2004; 127: 2018.

[31] Mirnics Z, Czikora G, Závecz T, et al. Changes in public attitudes toward epilepsy in Hungary: results of surveys conducted in 1994 and 2000. Epilepsia 2001; 42: 86-93. 
[32] Elsharkawy AE, May T, Thorbecke R, et al. Long-term outcome and determinants of quality of life after temporal lobe epilepsy surgery in adults. Epilepsy Res. 2009; 86: 191-199.

[33] Thorbecke R, Pfafflin M. Social aspects of epilepsy and rehabilitation. Handb Clin Neurol. 2012; 108: 983-999.

[34] Janszky J. Treatment and rehabilitation of epilepsy. In: Janszky J, Fogarasi A. (eds.) Clinical epileptology. [Az epilepszia gondozása és rehabilitációja. In: Janszky J, Fogarasi A. (szerk.) Klinikai epileptológia.] Medicina Könyvkiadó, Budapest, 2017; pp. 302304. [Hungarian]

[35] Thorbecke R, May TW, Koch-Stoecker S, et al. Effects of an inpatient rehabilitation program after temporal lobe epilepsy surgery and other factors on employment 2 years after epilepsy surgery. Epilepsia 2014; 55: 725-733.

[36] Michaelis R, Tang V, Wagner JL, et al. Psychological treatments for people with epilepsy. Cochrane Database Syst Rev. 2017; 10: $1-16$

[37] Pfafflin M, Petermann F, Rau J, et al. The psychoeducational program for children with epilepsy and their parents (FAMOSES): results of a controlled pilot study and a survey of parent satisfaction over a five-year period. Epilepsy Behav. 2012; 25: 11-16.

[38] Endermann M. Evaluation of the epilepsy basic training course IBF (Information, Counselling, Teaching) for staff members of services for people with disabilities. Rehabilitation 2010; 49: $160-172$.
[39] Rau J, May TW, Pfäfflin M. Education of children with epilepsy and their parents by the modular education program epilepsy for families (FAMOSES) - results of an evaluation study. Rehabilitation $2006 ; 45: 27-39$.

[40] Halász P, Sitku V. Actual questions of rehabilitation in patients living with epilepsy. [Az epilepsziával élők rehabilitációjának aktuális kérdései.] Rehabilitáció 1997; 7: 115-119. http://www. vitalitas.hu/olvasosarok/online/rehabilitacio/ 1997/3/2.htm [Hungarian]

[41] Tóth Z, Lukács G, Cselik Zs, et al. Hungarian clinical application opportunities of PET/MR imaging and first experiences. [A PET/MR képalkotás magyarországi klinikai alkalmazásának lehetőségei, elsố tapasztalatai.] Orv Hetil. 2018; 159: 13751384. [Hungarian]

[42] Békés J, Rásonyi G, Czikora G. Psychoeducational program for people with epilepsy. [Pszichoedukációs program epilepsziás betegek számára.] Rehabilitáció 2000; 10: 7-9. http://vitalitas. hu/olvasosarok/online/rehabilitacio/2000/ 1/4.htm [Hungarian]
(Gyimesi Csilla dr.,

Pécs, Rét u. 2., 7623 csilla.gyimesi@gmail.com)

\title{
MEGHÍV Ó
}

\section{A Szent János Kórház és Észak-budai Egyesített Kórházak Tudományos Bizottsága tisztelettel meghivja az érdeklődőket a következő tudományos ülésére.}

\author{
Időpont: 2019. február 21. (csütörtök) 14 óra
}

Helyszín: Szent János Kórház Auditóriuma - 1125 Budapest, Diós árok 1-3.

Téma: Tudományos ülés az időskorú betegek ellátásának speciális kérdéseiről

\author{
Üléselnök: Prof. Dr. Jánosi András
}

\section{Program:}

Prof. Dr. Székács Béla: Idős komorbid betegek integráló szemléletủ ellátása diagnosztikus, terápiás csapdák 20 perc

Prof. Dr. Winkler Gábor: Az idős korú cukorbetegek kezelésének fontosabb szempontjai 20 perc Prof. Dr. Kurimay Tamás: Az idős betegek pszichiátriai problémái és az ellátás szempontjai 20 perc Dr. Folyovich András: Stroke idős korban 20 perc

Minden érdeklődőt szeretettel várunk.

A cikk a Creative Commons Attribution 4.0 International License (https://creativecommons.org/licenses/by/4.0/) feltételei szerint publikált Open Access közlemény, melynek szellemében a cikk bármilyen médiumban szabadon felhasználható, megosztható és újraközölhető, feltéve, hogy az eredeti szerző és a közlés helye, illetve a CC License linkje és az esetlegesen végrehajtott módositások feltüntetésre kerülnek. (SID_1) 